\title{
Acquired von Willebrand syndrome secondary to Waldenström's macroglobulinemia
}

\author{
Satoko Hijii ${ }^{1}$, Taiichi Kodaka ${ }^{1}$, Takae Goka ${ }^{2}$, Yumi Aoyama ${ }^{1}$, Hiroko Tsunemine ${ }^{1}$, Takayuki Takahashi*1 \\ ${ }^{1}$ Department of Hematology, Shinko Hospital, Kobe, Japan \\ ${ }^{2}$ Department of Laboratory Medicine, Shinko Hospital, Kobe, Japan
}

Received: March 25, 2019

Accepted: June 18, 2019

Online Published: July 18, 2019

DOI: $10.5430 /$ crim.v6n3p13

URL: https://doi.org/10.5430/crim.v6n3p13

\begin{abstract}
Acquired von Willebrand (vW) syndrome in Waldenström's macroglobulinemia (WM) should be differentially diagnosed from hyperviscosity syndrome of WM, which exhibits a bleeding tendency. We report a rare case of acquired $\mathrm{vW}$ syndrome secondary to WM. A 62-year-old woman was referred to our hospital because of extensive subcutaneous hemorrhage following a light hit to the left arm. Although the platelet count was normal, APTT was prolonged to $49.4 \mathrm{sec}$. Furthermore, the serum concentration of IgM was elevated to $7,796 \mathrm{mg} / \mathrm{dL}$, which was revealed to be IgM- $\kappa$ monoclonal protein, leading to a diagnosis of WM. On ophthalmofundoscopy, mild hemorrhage, but not retinal vein dilatation, was observed. Regarding the abnormal APTT value, we measured coagulation factors in the intrinsic arm, revealing reduced activities of $\mathrm{vW}$ factor and factor VIII of 11 and $18 \%$, respectively. Furthermore, the amount of $\mathrm{vW}$ protein was decreased to $23 \%$. Multimer analysis of $\mathrm{vW}$ factor demonstrated an abnormal pattern lacking high-molecular-weight- bands. Additional diagnosis of acquired vW syndrome secondary to WM was made. The APTT cross-mixing test showed a simple but not inhibitor-related decreasing pattern of $\mathrm{vW}$ factor, suggesting the absorption of this factor by abnormal lymphoplasmacytic cells. The patient was treated with bendamustine, leading to reduced $\mathrm{IgM}$, improvement of the APTT value, and the normal multimer pattern of $\mathrm{vW}$ factor.
\end{abstract}

Key Words: Acquired von Willebrand syndrome, Waldenström's macroglobulinemia, Multimer analysis of von Willebrand factor, APTT cross-mixing test

\section{INTRODUCTION}

Acquired von Willebrand (vW) syndrome is a rare bleeding disorder with clinical and laboratory findings similar to those of congenital $\mathrm{vW}$ disease. ${ }^{[1-3]}$ Regarding the underlying disease of acquired $\mathrm{vW}$ syndrome, a large cohort of this disorder included lymphoproliferative (48\%), cardiovascular (21\%), myeloproliferative (15\%), neoplasia (5\%), immunological $(2 \%)$, and miscellaneous $(9 \%)$ disorders. ${ }^{[4,5]}$

As for the cause of decreasing $\mathrm{vW}$ factor, a number of pathogenic mechanisms have been reported, including $\mathrm{IgG}$ or IgM autoantibodies to $\mathrm{vW}$ factor, ${ }^{[2]}$ increasing $\mathrm{vW}$ factor clearance from plasma, ${ }^{[6]}$ absorption of $\mathrm{vW}$ factor by tumor cells, ${ }^{[7,8]}$ proteolytic cleavage of $\mathrm{vW}$ factor after shear stress caused by turbulent blood flow in cardiac valvular disease or cardiac device assistance, ${ }^{[9,10]}$ and decreased synthesis of normal $\mathrm{vW}$ factor (in hypothyroidism). ${ }^{[1]}$ The absorption mechanism has attracted attention in recent years in essential thrombocythemia (ET), in which excess numbers of platelet absorb vW factor resulting in a bleeding tendency. ${ }^{[12]}$ In $\mathrm{vW}$ syndrome in ET, platelet-derived microparticles or endothelial modulators such as nitric oxide, adenomedullin, or endothelin-1 may be involved in the pathogenesis. ${ }^{[13]}$ Here, we report a rare case of acquired $\mathrm{vW}$ syndrome secondary to

\footnotetext{
*Correspondence: Takayuki Takahashi; Email: takahashi.takayuki@ shinkohp.or.jp; Address: Department of Hematology, Shinko Hospital, 4-47, Wakihama-cho, 1-chome, Chuo-ku, Kobe 651-0072, Japan.
} 
Waldenström's macroglobulinemia (WM), in which absorption of vW factor by lymphoplasmasytic cells was suggested.

\section{Case presentation}

A 62-year-old female was referred and admitted to our hospital in October 2015 because of extensive subcutaneous hemorrhage following a light hit to the left arm, prolonged activated partial thrombin time (APTT) (49.4 seconds), and high serum concentration of $\operatorname{IgM}(7,796 \mathrm{mg} / \mathrm{dl})$. As for her medical history, she had hypertension but not bleeding disorder. No bleeding disorders were present in her family or relatives.

Physically, the hemorrhage in the left arm improved because of the time lag from the onset of hemorrhage. On ophthalmofundoscopy, mild hemorrhage, but not retinal dilatation or a choked disk, was observed. Neither superficial lymphadenopathy nor hepatosplenomegaly was noted.

Laboratory findings on admission are shown in Table 1 . The white cell count (WBC) was $4.9 \times 10^{9} / \mathrm{L}$ with a normal differential count, the hemoglobin concentration was $8.8 \mathrm{~g} / \mathrm{dl}$, and platelet count was $169 \times 10^{9} / \mathrm{L}$. A hemostat test showed prolonged APTT of 49.4 seconds (normally 25 to $35 \mathrm{sec}-$ onds). The serum concentration of IgM was $7,700 \mathrm{mg} / \mathrm{dl}$, and serum electrophoresis showed an M-peak that was revealed to be IgM- $\kappa$ type M protein by immunofixation. A bone marrow aspirate showed a number of lymphoplasmacytic cells, which comprised $15.6 \%$ of nucleated cells. These cells were positive for CD19, CD20, $\operatorname{smIgM,~} \operatorname{sm} \kappa, \operatorname{cyIgM}$, and $\mathrm{cy} \kappa$ but negative for CD56, CD138, $\operatorname{sm} \lambda$ and $\operatorname{cy} \lambda$. From these results, a diagnosis of WM was made.

Table 1. Laboratory data on admission

\begin{tabular}{|c|c|c|c|c|c|c|c|c|c|}
\hline \multicolumn{2}{|c|}{ Hematology } & \multicolumn{2}{|c|}{ Serology } & \multicolumn{2}{|c|}{ Hemostasis } & \multicolumn{2}{|c|}{ Chemistry } & \multicolumn{2}{|c|}{ Urinalysis } \\
\hline $\mathrm{RBC}$ & $2,980 \times 10^{9} / \mathrm{L}$ & CRP & $0.01 \mathrm{mg} / \mathrm{dl}$ & PT(\%) & $61 \%$ & AST & $13 \mathrm{U} / \mathrm{L}$ & GLU & $(-)$ \\
\hline $\mathrm{Hb}$ & $8.8 \mathrm{~g} / \mathrm{dl}$ & $\mathrm{TP}$ & $11.2 \mathrm{~g} / \mathrm{dl}$ & PT-INR & 1.25 & ALT & $5 \mathrm{U} / \mathrm{L}$ & PRO & $(+-)$ \\
\hline $\mathrm{Ht}$ & $27.9 \%$ & $\mathrm{~A} / \mathrm{G}$ & 0.4 & APTT & $49.4 \mathrm{sec}$ & ALP & $177 \mathrm{U} / \mathrm{L}$ & $\mathrm{BL}$ & $(+-)$ \\
\hline PLT & $169 \times 10^{9} / \mathrm{L}$ & ALB & $40.8 \%$ & FIB & $168 \mathrm{mg} / \mathrm{dl}$ & T.Bil & $0.8 \mathrm{mg} / \mathrm{dl}$ & BIL & $(-)$ \\
\hline WBC & $4.9 \times 10^{9} / \mathrm{L}$ & $\alpha 1$ & $1.7 \%$ & D-dimer & $0.5 \mu \mathrm{g} / \mathrm{ml}$ & $\gamma \mathrm{GTP}$ & $10 \mathrm{U} / \mathrm{L}$ & URO & $(+-)$ \\
\hline Neut & $71.6 \%$ & $\alpha 2$ & $4.8 \%$ & & & $\mathrm{ChE}$ & $268 \mathrm{U} / \mathrm{L}$ & & \\
\hline Eos & $0.4 \%$ & $\beta$ & $4.9 \%$ & & & $\mathrm{LDH}$ & $102 \mathrm{U} / \mathrm{L}$ & & \\
\hline Bas & $0.4 \%$ & $\gamma$ & $47.8 \%$ & & & $\mathrm{CK}$ & $80 \mathrm{U} / \mathrm{L}$ & & \\
\hline Mon & $4.8 \%$ & $\operatorname{Ig} \mathrm{A}$ & $26 \mathrm{mg} / \mathrm{dl}$ & & & AMY & $102 \mathrm{U} / \mathrm{L}$ & & \\
\hline Lym & $22.0 \%$ & IgG & $290 \mathrm{mg} / \mathrm{dl}$ & & & BUN & $12.4 \mathrm{mg} / \mathrm{dl}$ & & \\
\hline & & $\operatorname{IgM}$ & $7,700 \mathrm{mg} / \mathrm{dl}$ & & & CRE & $0.70 \mathrm{mg} / \mathrm{dl}$ & & \\
\hline & & & & & & UA & $5.2 \mathrm{mg} / \mathrm{dl}$ & & \\
\hline & & & & & & $\mathrm{Na}$ & $138 \mathrm{mEq} / \mathrm{L}$ & & \\
\hline & & & & & & K & $4.0 \mathrm{mEq} / \mathrm{L}$ & & \\
\hline & & & & & & $\mathrm{Cl}$ & $102 \mathrm{mEq} / \mathrm{L}$ & & \\
\hline & & & & & & $\mathrm{Ca}$ & $9.5 \mathrm{mg} / \mathrm{dl}$ & & \\
\hline & & & & & & T-CHO & $93 \mathrm{mg} / \mathrm{dl}$ & & \\
\hline & & & & & & TG & $56 \mathrm{mg} / \mathrm{dl}$ & & \\
\hline
\end{tabular}

Note. The normal limits of APTT, IgM, and IgG were 25 to 35 seconds, 46 to $260 \mathrm{mg} / \mathrm{dl}$, and 870 to $1,700 \mathrm{mg} / \mathrm{dl}$, respectively.

Because APTT was prolonged to 49.4 seconds, further examinations regarding coagulation factors in the intrinsic arm were performed, revealing reduced activities of $\mathrm{vW}$ factor and factor VIII of 11 and 18\%, respectively. Furthermore, the amount of $\mathrm{vW}$ protein (rate of normal value) was decreased to $23 \%$. Other coagulation factors including IX, X, XI, and XII factors were all within normal limits. Multimer analysis of $\mathrm{vW}$ factor ${ }^{[2,3,14]}$ demonstrated an abnormal pattern lacking high-molecular-weight bands (see Figure 1). The APTT cross-mixing test ${ }^{[15,16]}$ showed a downward convex pattern in both immediate and prolonged APTT assays (see Figure 2), suggesting a decreased amount of $\mathrm{vW}$ factor but not an inhibitor-related decreasing pattern of $\mathrm{vW}$ factor. An additional diagnosis of acquired $\mathrm{vW}$ syndrome was made.

WM of the present patient was treated with bendamustine; after 2 courses of this chemotherapy, the serum concentration of IgM was decreased to $3,342 \mathrm{mg} / \mathrm{dl}$ and APTT was normalized with a value of 36.6 seconds. The activities of $\mathrm{vW}$ factor and factor VIII, and the amount of $\mathrm{vW}$ protein (rate of normal value) were also improved to $42 \%, 58 \%$, and $57 \%$, respectively. The patient has since been periodically treated with retuximab, with serum IgM levels of around $3,000 \mathrm{mg} / \mathrm{dl}$, a normal APTT value, and no bleeding tendency as of March 2019. 


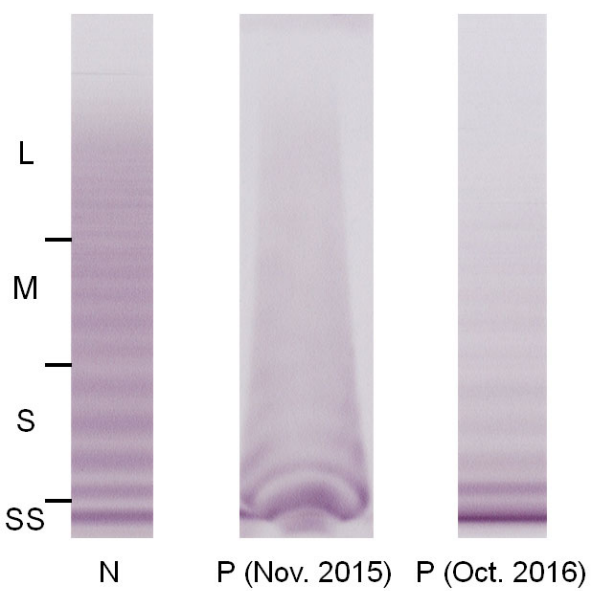

Figure 1. Multimer analysis of von Willebrand factor before and after chemotherapy for underlying Waldenstöm's macroglobulinemia. N: Normal multimer pattern from a healthy person. P (Nov. 2015): Multimer pattern from the present patient before chemotherapy. Characteristic distorted bands of low-molecular-weight factors were seen, and bands of high-molecular-weight factors were lost. $\mathrm{P}$ (Oct. 2016): Multimer pattern from the patient after chemotherapy. Almost the same pattern was seen when compared with the control $(\mathrm{N})$.

\section{Discussion}

In the present patient, hyperviscosity syndrome ${ }^{[17,18]}$ should be ruled out because the serum concentration of $\operatorname{IgM}$ was as high as 7,700 mg/dl. However, neither retinal vein dilatation nor a choked disk was observed on ophthalmofundoscopy; therefore, mild retinal bleeding may have been attributable to acquired $\mathrm{vW}$ syndrome.

Regarding the incidence of the association of WM and acquired $\mathrm{vW}$ syndrome, to the best of our knowledge, 50 cases of acquired $\mathrm{vW}$ syndrome in WM patients have been reported in the literature. ${ }^{[6,19-35]}$ Acquired $\mathrm{vW}$ syndrome in WM patients, therefore, may be rare, because WM is a relatively common disease. Hivert et al., however, reported that 10 patients fulfilled the criteria for acquired $\mathrm{vW}$ among 72 consecutive patients with WM. ${ }^{[29]}$ On the other hand, Kumar et al. described only 3 cases of WM among 20 cases of acquired $\mathrm{vW}$ syndrome in a single institution. ${ }^{[27]}$ Therefore, the exact incidence of acquired $\mathrm{vW}$ syndrome in $\mathrm{WM}$ is still to be clarified. Furthermore, the possibility of acquired $\mathrm{vW}$ syndrome should be taken into consideration even if the bleeding tendency has been tentatively attributed to hyperviscosity syndrome. ${ }^{[17,18]}$ In this situation, a screening test for APTT may be important.

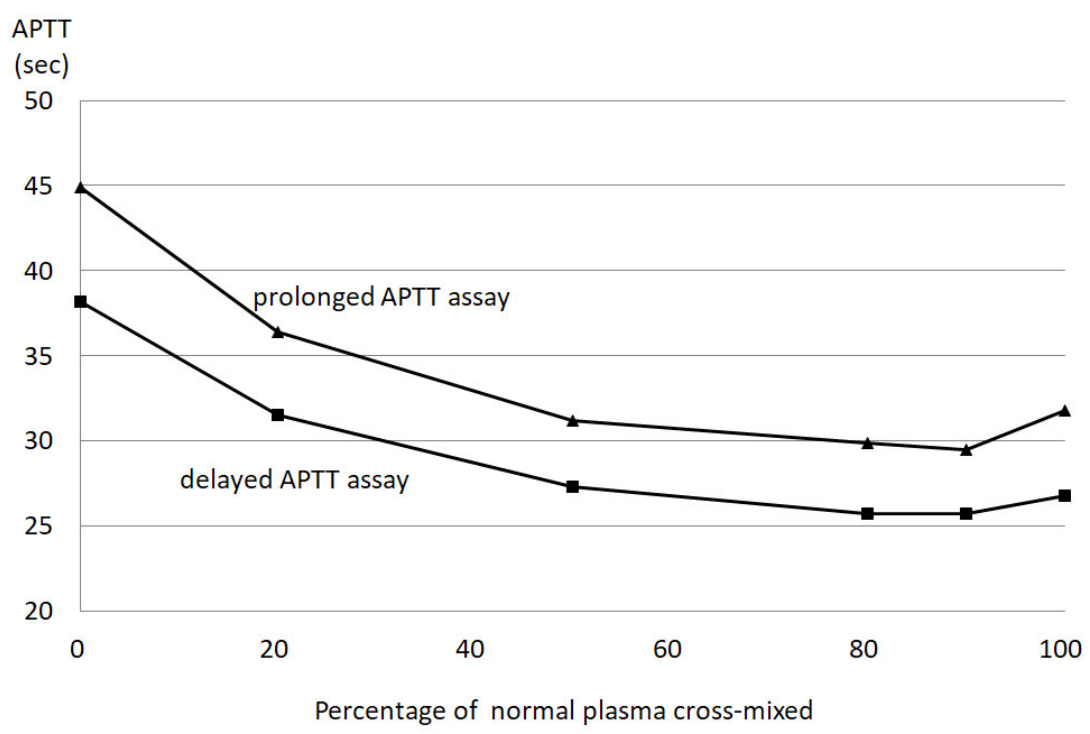

Figure 2. The APTT cross-mixing test before chemotherapy. The prolonged APTT of the patient's plasma was compensated by increasing concentrations of normal plasma showing a downward convex pattern in both immediate and prolonged APTT assays. For the prolonged APTT test, respective plasma specimens were incubated at $37^{\circ} \mathrm{C}$ for 120 min, and then APTT was measured.

As for the pathogenic mechanism of acquired $\mathrm{vW}$ syndrome in 50 reported WM patients, a number of mechanisms have been identified or suspected; first, IgG antibody against vW factor; ${ }^{[19]}$ second, some antibody against $\mathrm{vW}$ factor; ${ }^{[25]}$ third, possible IgM antibody against $\mathrm{vW}$ factor/dysfunction of $\mathrm{vW}$ by IgM paraprotein. ${ }^{[31,33]}$ Two cases in which plasmaphre- sis caused the remission of acquired $\mathrm{vW}$ syndrome might be classified into this category. ${ }^{[20,21]}$ The absorption of $\mathrm{vW}$ factor by tumor cells, ${ }^{[7,8]}$ as suggested in the present patient, was not described in these 50 patients with WM complicated by acquired $\mathrm{vW}$ syndrome. Similarly, the pathogenic mechanism of acquired $\mathrm{vW}$ syndrome was not examined or 
described in the majority of these 50 cases. We summarized the above identified or suspected pathogenic mechanisms of acquired $\mathrm{vW}$ syndrome in WM patients in Table 2.

Table 2. Identified or suspected pathogenic mechanisms of acquired vW syndrome in WM patients

\begin{tabular}{lccc}
\hline Cause of vW syndrome & Identified? & Suspected? & Ref. No. \\
\hline IgG antibody against vW factor & yes & no & 19 \\
IgM antibody against vW factor & no & yes & 31 \\
Some antibody against vW factor & no & yes & 25 \\
$\begin{array}{l}\text { Dysfunction of vW factor by IgM } \\
\text { paraprotein }\end{array}$ & no & yes & $20,21,33$ \\
$\begin{array}{l}\text { Absorption of vW factor by } \\
\text { lymphoplasmacytic tumor cells }\end{array}$ & no & yes & $\begin{array}{c}\text { Present } \\
\text { case }\end{array}$ \\
\hline
\end{tabular}

Note. vW: von Willebrand; WM: Waldenström's Macroglobulinemia.
In conclusion, acquired $\mathrm{vW}$ syndrome should be taken into consideration when a WM patient presents with a bleeding tendency even when hyperviscosity syndrome is suspected. In such a situation, screening tests of coagulation factors in the intrinsic arm, as well as APTT, are important.

\section{ACKNOWLEDGEMENTS}

The authors are grateful to Miss Mizue Higashi for her excellent support for manuscript preparation and literature search.

\section{Conflicts OF InTEREST Disclosure}

The author declares no conflict of interest

\section{REFERENCES}

[1] Mohri H. Acquired von Willebrand syndrome: features and management. Am J Hematol. 2006 Aug; 81(8): 616-23. PMid: 16823821. https://doi.org/10.1002/ajh. 20455

[2] Tiede A, Priesack J, Werwitzke S, et al. Diagnostic workup of patients with acquired von Willebrand syndrome: a retrospective single-centre cohort study. J Thromb Haemost. 2008 Apr; 6(4): 56976. PMid: 18208537 . https ://doi.org/10.1111/j.1538-783 6.2008.02909. $\mathrm{x}$

[3] Tiede A, Rand JH, Budde U, et al. How I treat the acquired von Willebrand syndrome. Blood. 2011 Jun 23; 117(25): 6777-85. PMid: 21540459. https://doi.org/10.1182/blood-2010-1 1-297580

[4] Federici AB, Rand JH, Bucciarelli P, et al. Subcommittee on von Willebrand Factor. Acquired von Willebrand syndrome: data from an international registry. Thromb Haemost. 2000 Aug; 84(2): 345-9. Erratum in: Thromb Haemost 2000 Oct; 84(4): 739. PMid: 10959711. https://doi.org/10.1055/s-0037-1614018

[5] Shetty S, Kasatkar P, Ghosh K. Pathophysiology of acquired von Willebrand disease: a concise review. Eur J Haematol. 2011 Aug; 87(2): 99-106. PMid: 21535159. https://doi.org/10.1111/j. 1600-0609.2011.01636.x

[6] Mannucci PM, Lombardi R, Bader R, et al. Studies of the pathophysiology of acquired von Willebrand's disease in seven patients with lymphoproliferative disorders or benign monoclonal gammopathies. Blood. 1984 Sep; 64(3): 614-21.

[7] Glaspy JA. Hemostatic abnormalities in multiple myeloma and related disorders. Hematol Oncol Clin North Am. 1992 Dec; 6(6): 130114. https : //doi .org/10.1016/S0889-8588(18) 30276-4

[8] Richard C, Cuadrado MA, Prieto M, et al. Acquired von Willebrand disease in multiple myeloma secondary to absorption of von Willebrand factor by plasma cells. Am J Hematol. 1990 Oct; 35(2): 114-7. PMid: 2205095. https://doi .org/10.1002/ajh. 2830350210

[9] Vincentelli A, Susen S, Le Tourneau T, et al. Acquired von Willebrand syndrome in aortic stenosis. N Engl J Med. 2003 Jul; 349(4): 343-9. PMid: 12878741. https://doi.org/10.1056/NEJMoa02 2831.

[10] Koliopoulou A, McKellar SH, Rondina M, Selzman CH. Bleeding and thrombosis in chronic VAD therapy: focus on platelets. Curr Opin Cardiol. 2016 May; 31(3): 299-07. PMid:27054505. https://doi.org/10.1097/HCD.0000000000000284
[11] Michiels JJ, Schroyens W, Berneman Z, van der Planken M. Acquired von Willebrand syndrome type 1 in hypothyroidism: reversal after treatment with thyroxine. Clin Appl Thromb Hemost. 2001 Apr; 7(2): 113-5. PMid:11292187. https://doi.org/10.1177/10760296 0100700206

[12] Lancellotti S, Dragani A, Ranalli P, et al. Qualitative and quantitative modifications of von Willebrand factor in patients with essential thrombocythemia and controlled platelet count. J Thromb Haemost. 2015 Jul; 13(7): 1226-37. PMid: 25876231. https: //doi.org/10.1111/jth.12967.

[13] Piccin A, Steurer M, Feistritzer C, et al. Observational retrospective study of vascular modulator changes during treatment in essential thrombocythemia. Transl Res. 2017 Jun; 184: 21-34 PMid:28259616. https://doi.org/10.1016/j.trsl.2017.02 .001

[14] Van Belle E, Rauch A, Vincent F, et al. Von Willebrand Factor Multimers during Transcatheter Aortic-Valve Replacement. N Engl J Med. 2016 Jul; 375(4): 335-44.

[15] Rosner E, Pauzner R, Lusky A, Modan M, Many A. Detection and quantitative evaluation of lupus circulating anticoagulant activity. Thromb Haemost. 1987 Apr 7; 57(2): 144-7. PMid: 3110995 https://doi.org/10.1055/s-0038-1651083

[16] Pengo V, Tripodi A, Reber G, et al. Subcommittee on Lupus Anticoagulant/Antiphospholipid Antibody of the Scientific and Standardisation Committee of the International Society on Thrombosis and Haemostasis. Update of the guidelines for lupus anticoagulant detection. Subcommittee on Lupus Anticoagulant/Antiphospholipid Antibody of the Scientific and Standardisation Committee of the International Society on Thrombosis and Haemostasis. J Thromb Haemost. 2009 Oct; 7(10): 1737-40. PMid: 19624461. https : //doi.org/10.1111/j.1538-7836.2009.03555.x

[17] Bloch KJ, Maki DG. Hyperviscosity syndromes associated with immunoglobulin abnormalities. Semin Hematol. 1973 Apr; 10(2): 113-24. PMid: 4633222.

[18] Reinhart WH, Lutolf O, Nydegger UR, Mahler F, Straub PW. Plasmapheresis for hyperviscosity syndrome in macroglobulinemia Waldenström and multiple myeloma: influence on blood rheology and the microcirculation. J Lab Clin Med. 1992 Jan; 119(1): 69-76. PMid: 1727909.

[19] Mazurier C, Parquet-Gernez A, Descamps J, Bauters F, Goudemand M. Acquired von Willebrand's syndrome in the course of Walden- 
ström's disease. Thromb Haemost. 1980 Dec 19; 44(3): 115-8. PMid: 6781094. https://doi.org/10.1055/s-0038-1650099

[20] Silberstein LE, Abrahm J, Shattil SJ. The efficacy of intensive plasma exchange in acquired von Willebrand's disease. Transfusion. 1987 May-Jun; 27(3): 234-7. PMid: 3109084. https ://doi.org/10.1 046/j.1537-2995.1987.27387235627 .x

[21] Thies K, Budde U, Hellstern P. [Hemostatic therapy in a patient with acquired von Willebrand disease and Waldenström disease with plasmapheresis and DDAVP]. Beitr Infusionsther. 1990; 26: 179-82. PMid: 1703824. [Article in German]

[22] Berentsen S, Hammerstrøm J. [Acquired von Willebrand's disease]. Tidsskr Nor Laegeforen. 1993 May 10; 113(12): 1463-5. PMid: 8332973. [Article in Norwegian]

[23] Hennessy BJ, White B, Byrne M, Smith OP. Acquired von Willebrand's disease. Ir J Med Sci. 1998 Apr-Jun; 167(2): 81-5. PMid: 9638020. https://doi.org/10.1007/BF02937942

[24] Hunault-Berger M, Rachieru P, Ternisien C, et al. Acquired von Willebrand disease and lymphoproliferative syndromes. Presse Med. 2001 Feb; 30(5): 209-12. PMid: 12385052 [Article in French]

[25] Arai M. Immune coagulation disorders (excluding antiphospholipid syndrome. Rinsho Byori. 2001 Oct; 49(10): 1000-4. PMid: 11769464. [Article in Japanese]

[26] Casares PZ, Gillet DS, Verity DH. Bilateral simultaneous central retinal vein occlusion (CRVO) caused by waldenstrom's macroglobulinaemia with acquired von willebrand's disease. Br J Haematol. 2002 Jul; 118(1): 344-7. PMid: 12100172. https ://doi .org/10 .1046/j.1365-2141.2002.03576_1.x

[27] Kumar S, Pruthi RK, Nichols WL. Acquired von Willebrand's syndrome: a single institution experience. Am J Hematol. 2003 Apr; 72(4): 243-7. PMid: 12666134. https://doi.org/10.1002/aj h. 10298

[28] Voisin S, Hamidou M, Lefrançois A, et al. Acquired von Willebrand syndrome associated with monoclonal gammopathy: a single-center study of 36 patients. Medicine (Baltimore). 2011 Nov; 90(6): 404 11. PMid: 22033454. https://doi.org/10.1097/MD.0b013e3 182397166

[29] Hivert B, Caron C, Petit S, et al. Clinical and prognostic implications of low or high level of von Willebrand factor in patients with Waldenstrom macroglobulinemia. Blood. 2012 Oct 18; 120(16): 3214-21. PMid: 22896002. https://doi.org/10.1182/blood-2011-1 1-388256

[30] Coucke L, Marcelis L, Deeren D, et al. Lymphoplasmacytic lymphoma exposed by haemoptysis and acquired von Willebrand syndrome. Blood Coagul Fibrinolysis. 2014 Jun; 25(4): 395-7. PMid: 24469392. https://doi.org/10.1097/MBC. 00000000000000 52

[31] Ackerstaff S, Dittmer R, Sucker C. 66-year old female patient with vitreous and mucosal bleeding. Dtsch Med Wochenschr. 2016 Feb; 141(4): 271-4. PMid: 26886041. https://doi.org/10.1055/ s-0042-100377 [Article in German]

[32] Ouyang HY, Yu ZJ1, Yin J, et al. Acquired von Willebrand syndrome in three patients and literature review. Zhonghua Xue Ye Xue Za Zhi. 2016 Aug 14; 37(8): 692-5. PMid: 27587252. https://doi.or $\mathrm{g} / 10.3760 / \mathrm{cma} \cdot \mathrm{j} . \mathrm{issn} .0253-2727.2016 .08 .012$ [Article in Chinese]

[33] Dicke C, Schneppenheim S, Holstein K, et al. Distinct mechanisms account for acquired von Willebrand syndrome in plasma cell dyscrasias. Ann Hematol. 2016 May; 95(6): 945-57. PMid: 27040683. https://doi.org/10.1007/s00277-016-2650-x

[34] Wolfe Z, Lash B. Acquired von Willebrand Syndrome in IgM Monoclonal Gammopathy as the Presentation of Lymphoplasmacytic Lymphoma. Case Rep Hematol. 2017; 2017: 9862620. PMid: 28695028. https ://doi.org/10.1155/2017/9862620

[35] Mohamed M. Waldenstrom macroglobulinaemia manifesting as acquired von Willebrand syndrome. Intern Med J. 2018 Jul; 48(7): 888891. PMid: 29984508. https ://doi.org/10.1111/imj . 13941 